\title{
Toxicity of an Organophosphate Pesticide (chloropyrifos) on a common Niger Delta Wetland Fish -Tilapia guineensis (Blecker 1862)
}

\author{
${ }^{1}$ CHINDAH, A C; ${ }^{2}$ SIKOKI; F D; ${ }^{2}$ VINCENT-AKPU, IJEOMA
}

\author{
${ }^{1}$ Institute of Pollution Studies, Rivers State University of Science and Technology, PMB 5080 Nkpolu Oroworukwo, Port Harcourt \\ ${ }^{2}$ Department of Animal and Environmental Biology, University of Port Harcourt, PMB 5323, Port Harcourt, Nigeria
}

\begin{abstract}
The acute and sublethal toxicity of an organophosphate pesticide (Chloropyrifos) on the juvenile of Tilapia guineensis was evaluated to determine its effect on the survival, body functions and heamatological values. The fish was exposed to varying levels of the toxicant $(0.0125 \mathrm{mg} / \mathrm{l} ; 0.025 \mathrm{mg} / \mathrm{l} ; 0.05 \mathrm{mg} / \mathrm{l}$ and $0.1 \mathrm{mg} / \mathrm{l})$ using $96 \mathrm{hrs}$ static bioassay to determine the median lethal concentration and median lethal time for the different concentrations. The mortality was found to increase with exposure and increase in concentration. The 96hrs median lethal concentration was $0.002 \mathrm{mg} / \mathrm{l}$ while the $96 \mathrm{hr}$ median lethal time of $56.2 \mathrm{hrs}$; $42.7 \mathrm{hrs}$; $31.1 \mathrm{hrs}$ and $18.2 \mathrm{hrs}$ were recorded for $0.0125 \mathrm{mg} / \mathrm{l} ; 0 . .025 \mathrm{mg} / \mathrm{l}, 0.05 \mathrm{mg} / \mathrm{l}$ and $0.1 \mathrm{mg} / \mathrm{l}$ respectively. The operculum beat frequency $(\mathrm{F}=\mathrm{Cal} 6.89>\mathrm{P}=3.49$ ) 0.05 and Tail beat frequency $(\mathrm{F}=\mathrm{Cal} 4.46>\mathrm{P}(3.49)$ o. 05 were significantly affected by the exposure. A sublethal exposure to various concentrations $(0.0006 \mathrm{mg} / \mathrm{l} ; 0.00125 \mathrm{mg} / \mathrm{l}, 0.0025 \mathrm{mgl}, 0.005 \mathrm{mg} / \mathrm{l})$ were observed to cause a progressive reduction in the number of leucocyte ( $\mathrm{F}-\mathrm{Cal} 15.4>\mathrm{P}(3.01)_{0.05}$ and erythrocyte (F- Cal $14.39>\mathrm{P}(3.01)_{0.05}$ of the fish.The reduction in leucocye and erythrocyte number was significant indicating that the fish became anaemic.These conditions were more severe in the higher concentrations of the pesticide. @JASEM
\end{abstract}

Until recently, the adverse effects of pesticides and their residue on non-target organisms have not been seriously considered in Nigeria. Pesticides are often applied directly on agricultural land, primarily to control pest and improve crop yield to meet the high demand for food needed by the fast growing population. These pesticides applied in the field or those by accidentally spills of pesticides and careless discarding of pesticide containers; finally find their way into the aquatic environment either through storm water run off and or as aerosols carried by wind. Pesticides have been report to have negative ecological consequences on biota and the environment at large. On biota, the effect on the physiological processes (Singh et al 1992) reproductive failure (Bostveld et al 1993, Bostveld et al 1995), mortality (Dieter et al 1995); and instability in the ecosystem function (Bostveld et al 1993 and 1995, Grues, 198) have been reported. In Nigeria, similar studies have centered mainly on crude oil and petroleum products toxicity on aquatic organisms (Omoregie et al 1990; Dambo 1993, Omoregie 1995, Chindah 1998, Chindah et al 2001). Nonetheless, studies on pesticides toxicity are scanty despite several decades of its introduction, the wide use and magnitude (Chindah et al 2000). Therefore this study aims at determining the effect of a major organophosphate pesticide (chloropyrifos) used against soil insects of field and vegetable crops on fish mortality, body function and circulatory fluids on a common Tilapine fish species (Tilapia guineensis) prevalent in the Niger Delta waters.

\section{MATERIALS AND METHODS}

Tilapia guineensis of almost uniform length $(5.5 \pm 0$ .8. $\mathrm{cm})$ and weight $(3.4 \pm 0.3 \mathrm{~g})$ were collected with hand net from its natural habitat and held in holding tanks for 2 weeks prior to the experiment. The holding tanks were aerated, cleaned and water renewed daily. Fish were fed twice daily with NIOMR feed (pellets of $10 \%$ body weight).

Toxicity was determined by renewal static bioassay. All experiments were conducted in 15 rectangular glass aquaria ( $25 \times 60 \times 25 \mathrm{~cm}$ ) containing 20 litres of brackish water to which volumes of chlorphyfos was added to achieve different concentrations of the toxicant. Thirty minutes after the preparation of test solution, 20 juveniles fishes were carefully placed into each replicate tanks of 5 different concentrations $(0.1 \mathrm{mg} / 1,0.5 \mathrm{mg} / 1,0.025 \mathrm{mg} / 1,0.0125 \mathrm{mg} / 1$, and control $0.00 \mathrm{mg} / 1$ ). All experiments were conducted at room temperature and the tanks aerated. Fish were not fed during the experiment (Reish and Oshida 1986).

Observations were recorded every $12 \mathrm{hrs}$; number of dead fish were removed. The tail beat and opercular beat frequencies were taken every 24hrs. Experiment lasted for 96hrs for the different concentrations of chloropyrifos. The susceptibility of fish to insecticide

*Corresponding author

Email: alexchindah@hotmail.com 
was determined using probit method for $\mathrm{LC}_{50}$ at 96hrs.

From the result of acute toxicity, sublethal concentrations $(0.005 \mathrm{mg} / 1,0025 \mathrm{mg} / 1,0.00125 \mathrm{mg} / 1$, and $0.0006 \mathrm{mg} / 1$ ) were prepared. Ten glass aquaria were used with 2 replicates per treatment and with the same conditions as in acute toxicity. Group of 10 fish $(9 \pm 1.2 \mathrm{~g}, 7.4 \pm 1.3 \mathrm{~cm}$ TL) were exposed to different concentration for 8 weeks. During which freshly prepared test solution were added on regular basis to maintain the concentration level after the waste were siphoned out. The water was changed once weekly and the tanks cleaned daily.. Fish and water quality parameters (Temperature, $\mathrm{pH}$, salinity, conductivity, alkalinity, and Dissolved Oxygen) of the test solution were monitored through the duration of the experiment.

Every forth night, 2 fishes were sacrificed and blood collected using insulin syringe and needle (size) that were rinsed with EDTA to determine the various hematological parameters. The significant differences among means were tested with 2-way analysis of variance (ANOVA, 0.05).

\section{RESULTS}

The water quality parameters (Temperature, dissolved oxygen, salinity, alkalinity, $\mathrm{pH}$ conductivity) monitored during the exposure period did not differ within the various concentrations of pesticides as well as with the control. $\mathrm{pH}$ and alkalinity values tended to increase with increasing concentrations of the test chemical, however, values between treatments were not significantly different (ANOVA, $\mathrm{P}<0.05$ ). Temperature and dissolved oxygen values were almost uniform all through the study irrespective of the treatment. Similarly, salinity and conductivity values exhibited minimal variation in values, which were statistically not significant within and between treatments (ANOVA, P < 0.05). The limited variation in the physicochemical variables is similar to the trend observed in the wild, which is tolerated by the test organism even in the wild (Table 1).

Table 1: Mean concentration (ppm), range and standard deviation of physiochemical parameters for chloropyrifos treated tanks.

\begin{tabular}{|l|l|l|l|l|l|l|}
\hline Conc. & \multicolumn{1}{|c|}{$\mathrm{pH}$} & \multicolumn{1}{|c|}{ Temp $\left({ }^{\circ} \mathrm{C}\right)$} & DO $(\mathrm{mg} / \mathrm{l})$ & Salinity $\left({ }^{\circ} \mathrm{O}_{\mathrm{oo}}\right)$ & Conductivity $(\mu \mathrm{S} / \mathrm{cm})$ & Alkalinity $(\mathrm{mg} / \mathrm{l})$ \\
\hline 0 & $6.93 \pm 0.15$ & $27.7 \pm 0.30$ & $3.98 \pm 0.32$ & $15.9 \pm 0.08$ & $25850 \pm 129.1$ & $76.4 \pm 7.3$ \\
& $(6.7-7.0)$ & $(27.3-27.9)$ & $(3.5-4.1)$ & $(5.8-16.0)$ & $(25700-26000)$ & $(69.8-86.8)$ \\
\hline 0.0125 & $6.98 \pm 0.15$ & $27.6 \pm 0.36$ & $3.95 \pm 0.32$ & $17.1 \pm 0.87$ & $27650 \pm 1369.9$ & $78.8 \pm 5.9$ \\
& $(6.9-7.1)$ & $(27.1-27.9)$ & $(3.75-4.42)$ & $(15.8-17.6)$ & $(25000-28400)$ & $(70.0-84.2)$ \\
\hline 0.025 & $6.98 \pm 0.15$ & $27.5 \pm 0.36$ & $3.97 \pm 0.45$ & $17.1 \pm 0.89$ & $27725 \pm 1381.7$ & $80.4 \pm 9.2$ \\
& $(6.8-7.1)$ & $(27.1-27.8)$ & $(3.59-4.62)$ & $(15.8-17.8)$ & $(25700-28800)$ & $(70-91.6)$ \\
\hline 0.05 & $7.03 \pm 0.05$ & $27.5 \pm 0.50$ & $3.94 \pm 0.40$ & $16.83 \pm .68$ & $27250 \pm 1066.1$ & $81.1 \pm 8.7$ \\
& $(7.0-7.1)$ & $(27.0-28)$ & $(3.62-4.61)$ & $(15.9-17.5)$ & $(25800-28300)$ & $(69.6-90.2)$ \\
\hline 0.1 & $7.05 \pm 0.05$ & $27.5 \pm 0.48$ & $3.91 \pm 0.50$ & $16.68 \pm 0.39$ & $27125 \pm 485.6$ & $86.1 \pm 7.94$ \\
& $(7.0-7.1)$ & $(26.9-27.9)$ & $(3.52-4.61)$ & $(16.1-16.9)$ & $(26400-27400)$ & $(85.2-92.0)$ \\
\hline
\end{tabular}

Mortality: Data on survival of $T$. guineensis to chlorphyfos is shown in Fig. 1. No mortality was observed in the control, however mortality increased as concentration and time increased. Ten (10) percent mortality was recorded in $0.0125 \mathrm{mg} / \mathrm{L}$ concentration tank at $24 \mathrm{hrs}$, this value increased to $32 \%$ in $36 \mathrm{hrs}$, $38 \%$ in $48 \mathrm{hrs}$, $52 \%$ in $60 \mathrm{hrs}, 62 \%$ in $72 \mathrm{hrs}, 78 \%$ in 84hrs and $85 \%$ in $96 \mathrm{hrs}$ respectively, thus indicating increased mortality over time. At $0.025 \mathrm{mg} / \mathrm{L}$ concentration, $22 \%$ mortality was observed in $24 \mathrm{hrs}$ followed by $45 \%, 50 \%, 67 \%, 77 \%, 82 \%$, and $92 \%$ for 36hrs, 48hrs, 60hrs, 72hrs, 84hrs, and 96hrs respectively. The fish exposed to $0.05 \mathrm{mg} / \mathrm{L}$ concentration had mortality sequence of $38 \%$ (24hrs) < 63\% (36hrs) < 77\% (48hrs) < 88\% (60hrs) < $95 \%$ (72hrs) $<100 \%$ (84hrs) $=100 \%$ (96hrs). Similarly, at $0.1 \mathrm{mg} / \mathrm{L}$ concentration, high mortality values of $68 \%$ and $88 \%$ were recorded for $24 \mathrm{hrs}$ and $36 \mathrm{hrs}$ respectively. Slight increase was observed in 48hrs (95\%) and 60hrs (97\%) until 100\% mortality was observed in $72 \mathrm{hrs}$. The $96 \mathrm{hrs} \mathrm{LC}_{50}$ was $0.002 \mathrm{mg} / \mathrm{l}$ and the $\mathrm{LT}_{50}$ for $0.0125 \mathrm{mg} / 1 ; 0.025 \mathrm{mg} / \mathrm{l}$; $0.05 \mathrm{mg} / \mathrm{l}$ and $0.1 \mathrm{mg} / \mathrm{l}$ were $56.2 \mathrm{hrs} 42.7 \mathrm{hrs}, 31.1 \mathrm{hrs}$ and 18.2hrs respectively (figure 2). The $\mathrm{LT}_{50}$ decrease with increase in concentration while the $\mathrm{LC}_{50}$ decreases as time increase (Fig.3). The influence of chlorphyfos concentration on mortality was significant with F cal (23.85) $>\mathrm{P}=3.26_{0.05}$. 


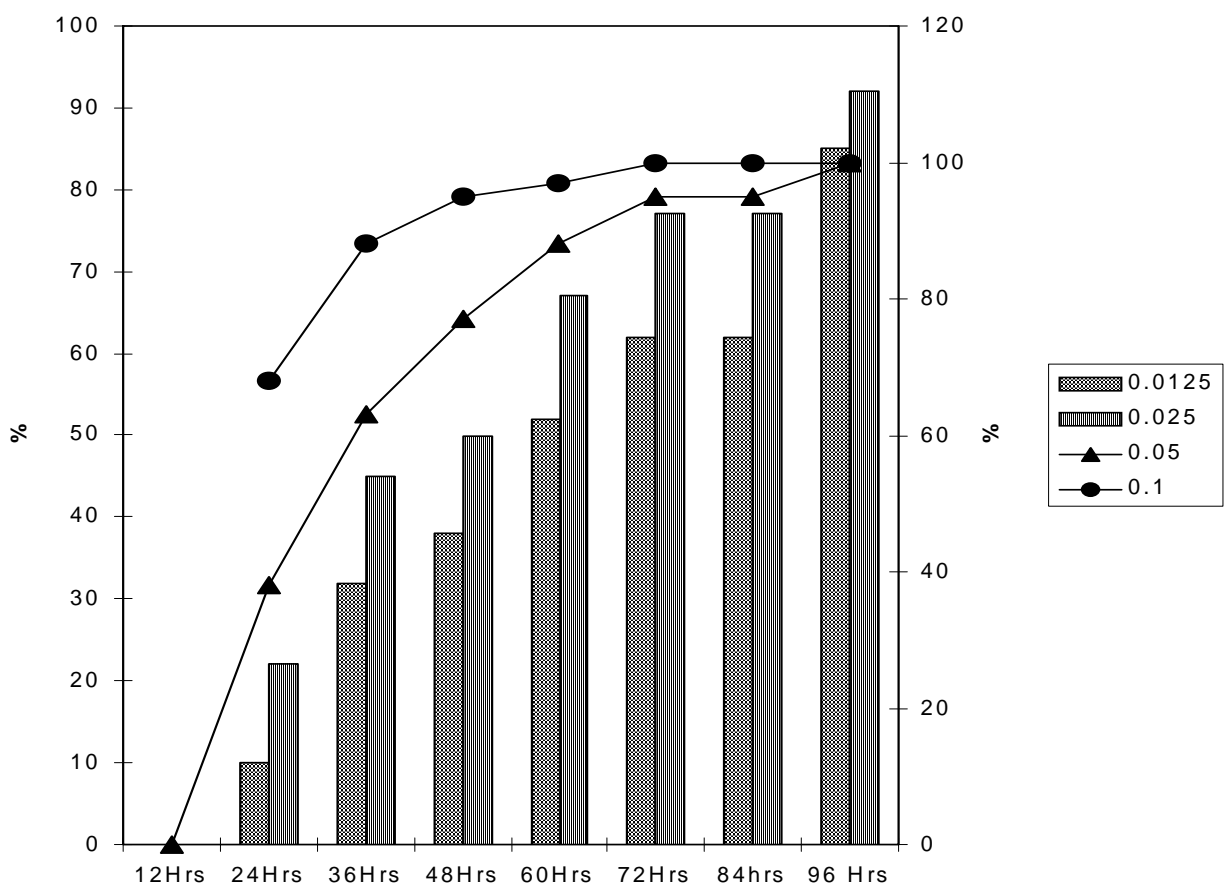

Fig 1: Percentage mortality of Tilapia guineensis expose for several hours of exposure at different concentrations of chloropyrifos

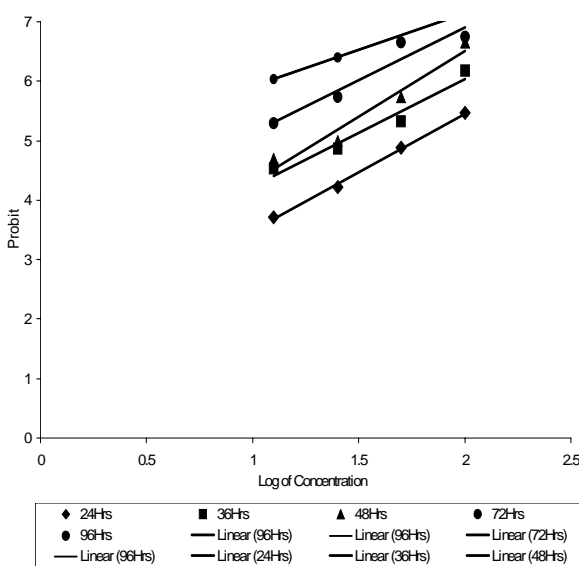

Fig 2 . Probit plot of Tilapia guineensis mortality against log of chloropvrifos concentrations

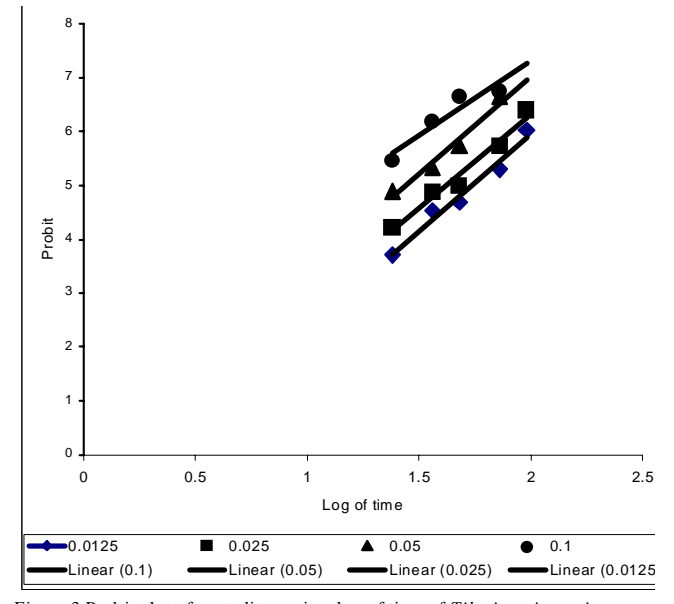

Figure 3 Probit plot of mortality against log of time of Tilapia guineensis expose to various concentrations of chloropyrifos.
Opercular Beat Frequency (OBF): The effect of chlorphyfos on OBF of $T$. guineensis In all cases, except the control fish that shows relatively uniform value (91-92 counts/minutes) Table 2. A progressive and significance $\left(\mathrm{F}-\mathrm{cal}(6.89)>\mathrm{P}=3.49_{0.05}\right)$ decline in OBF values was observed with exposure time.

Tail Beat Frequency (TBF): The fishes in the control experiment showed limited variation in the TBF whereas other treatments had an initial increases values at the $24 \mathrm{hrs}$, which declined after $48 \mathrm{hrs}$ (Table 3) statistical analysis revealed that there was significant difference in the TBF between the treatments $\left(\mathrm{F} \mathrm{cal}(4.46)>\mathrm{P}=3.49_{0.05}\right)$.

Leucocyte and Erythrocyte: In addition, significant (F cal $\left.(15.4)>P=3.01_{0.05}\right)$ reduction in leucocytes and erythrocytes values was observed at chlorphyfos sublethal concentrations. The erythrocyte (RBC) and Leucocytes (WBC) values for treated fish (Table 4) indicated significant decline for both the leucocyte $(\mathrm{F}$ cal $\left(15.4_{0.05}\right)>\mathrm{P}=3.01$ ) and erythrocyte ( $\mathrm{F}$ cal (14.39) $>\mathrm{P}=3.01_{0.05}$ ) when compared with the reference fish. 
Table 2: Summary of OBF values of Tilapia guineensis exposed to various concentrations of chloropyrifos in 96 hours.

\begin{tabular}{|l|c|l|l|l|l|}
\hline \multirow{2}{*}{$\begin{array}{l}\text { Exposure } \\
\text { Time (hr) }\end{array}$} & 0.0 & 0.0125 & 0.025 & 0.05 & 0.1 \\
\cline { 2 - 6 } & control & & $122 \pm 1.7$ & $130 \pm 0$ & $145 \pm 5$ \\
\hline 24 & $90.7 \pm 0.6$ & $106.3 \pm 5.5$ & & & \\
\hline 48 & $92.3 \pm 2.5$ & $93.7 \pm 5.5$ & $113.3 \pm 2.9$ & $45.3 \pm 5.5$ & $30.3 \pm 0.6$ \\
\hline 72 & $90 \pm 0$ & $58.3 \pm 2.9$ & $102.7 \pm 3.8$ & $30 \pm 0$ & $20.7 \pm 1.2$ \\
\hline 96 & $91.3 \pm 1.5$ & $42 \pm 2.6$ & $48 \pm 2.6$ & $19.5 \pm 0.7$ & - \\
\hline
\end{tabular}

Table 3: Tail Beat Frequency of T.guineensis exposed to various concentrations of chloropyrifos in 96 hours.

\begin{tabular}{|l|c|l|l|l|l|}
\hline \multirow{2}{*}{$\begin{array}{l}\text { Exposure } \\
\text { Time (hr) }\end{array}$} & 0.0 & 0.0125 & 0.025 & 0.05 & 0.1 \\
\cline { 2 - 6 } & Control & & & \\
\hline 24 & $7.3 \pm 0.6$ & $11 \pm 1.7$ & $15.3 \pm 2.5$ & $18.7 \pm 0.6$ & $25 \pm 5$ \\
\hline 48 & $7.7 \pm 0.6$ & $9.7 \pm 0.6$ & $11.7 \pm 2.9$ & $4.3 \pm 0.6$ & $2.7 \pm 0.6$ \\
\hline 72 & $7.3 \pm 0.6$ & $4.7 \pm 0.6$ & $5 \pm 2$ & $2 \pm 0$ & $1.7 \pm 0.6$ \\
\hline 96 & $7 \pm 0$ & $3 \pm 1$ & $2.3 \pm 1.5$ & $1 \pm 0$ & - \\
\hline
\end{tabular}

\section{DISCUSSION}

The observed increase in OBF and TBF within 24 hours of exposure to chloropyrifos and decline thereafter had been reported earlier by Omoregie (1995). The initial increases in OBF and TBF may be associated with the sudden response to shock. In addition, the behavioural response to chloropyrifos with marked deviation in the rate of OBF and TBF from reference sample (control) imputes an adjustment in physical fitness as a result of the stress condition (Edwards and Fusher 1991, Leight and Van Dolah 1999). Grillitsch et al. (1999) reported that organisms exhibit behavioural responses to chemical stress both at acute and sublethal toxicity. This elicits the potency and sensitivity of the fish - Tilapia guineensis to the test chemical. The ecological importance of this is that the damage to non-target species in the environment and such attribute of the organism could be effectively used as toxicity biosensor of chemical stress. Other studies on different toxicants especially petroleum related hydrocarbon compounds indicated damage to epithelial cells of the gill chamber (Omoregie 1995), destruction of liver (Omoregie 1995), possible nervous breakdown, failing organs and retarded physiological processes in fish body functions (Omoregie 1995 Meyer et al. 1992 and Fryday et al
1996). Chindah et al (2001) noted that aquatic organisms (shell and fin fishes) which is indirect continuous contact with the medium in addition to breathing and feeding will be vulnerable to respiratory tract damage and other organs of the body.

The result of haemotological parameters showed marked reduction between control fish and the fish exposed to different concentrations of chloropyrifos, which is an indication of the deleterious effects of the chemical pollutant to the body fluid. The most adverse effects were observed in the fish exposed to $0.1 \mathrm{mg} / \mathrm{l}$ of the toxicant. In consistence with our data, other research has shown a reduction in these parameters in fish exposed to various toxic environments (Omeregie et. al 1990; Sikoki \& Enajekpo 1991; Wedemayer and Yasutake 1977 and Singh et al 1992). Reduction in erythrocyte and leucocyte reported in this investigation indicated that Tilapia guineensis exposed to sublethal concentration of chloropyrifos became anaemic and leukopenia (Kerting and van Wijngaarden1992). This according to Hontela et al. (1992) is due to hemodilution resulting from impaired osmoregulation across the gill epithelium. The change in osmoregulation such as plasma osmolarity which is associated with rise in blood volume and tissue water content suggesting increased influx of water through the gills from 
changes in gills permeability to water, a failure of electrolyte regulatory mechanism (MCLeese et al 1980, Scheck 1990, Weber and Spieler 1994, Hontela et al. 1992,, Habig and Guillo 1991). In view of the multifarious uses of agrochemical (pesticides) by man, their ecological effects must always be kept in mind. Our results confirm the views of other researchers in this field, that the pesticide chloropyrifos have deleterious effects on the survival, body and haematological processes in T. guineensis (Singh and Narain1982, Singh et al 1992). The sublethal dose in the wild may in addition cause growth lag, reproductive failure and/or death (Stein et al 1992, USEPA 1995, Pratt and Cairns 1996).

Table 4: The average leucocytes and erythrocyte of $T$. guineensis after 8 weeks of exposure to various concentrations of Chloropyrifos

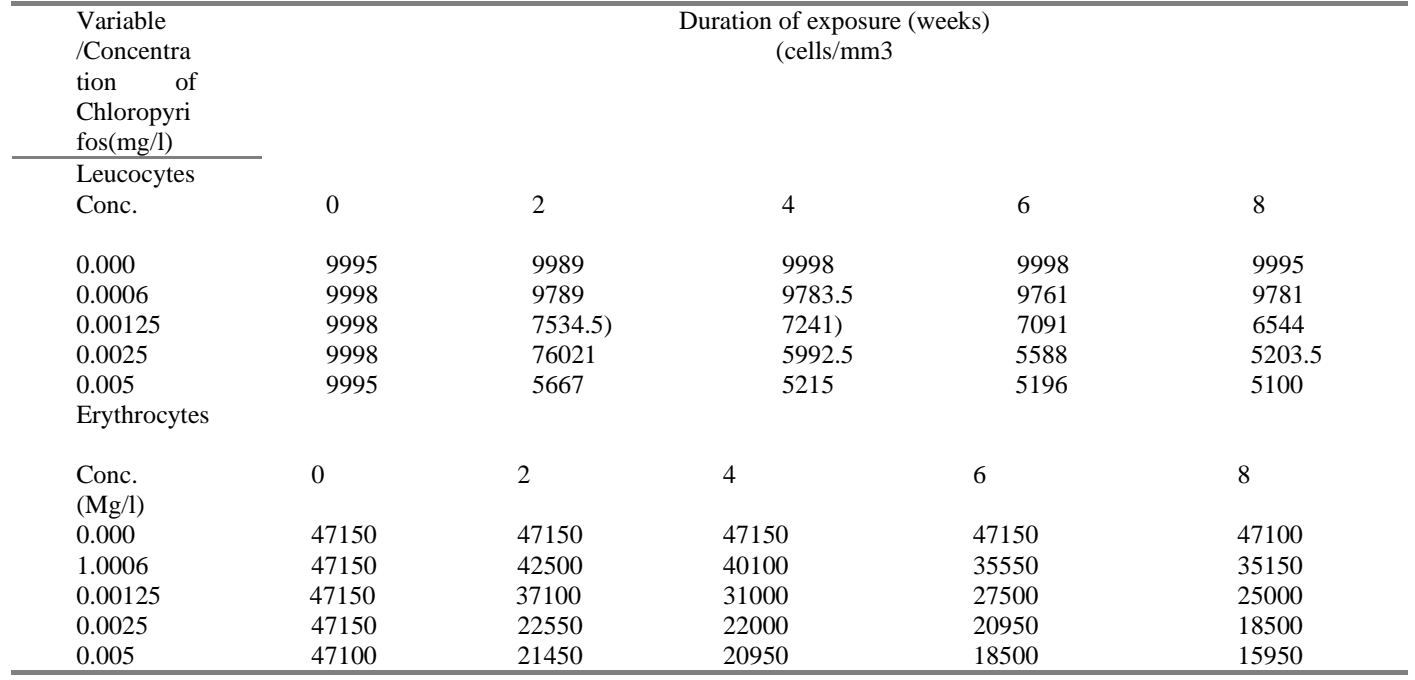

It is therefore our view that effort should be made to study the levels of pesticides in our natural water bodies and adjoining environment in order to provide baseline data, which could be used as a strategy for assessing the distribution, impact of contaminants on specific areas and the ecological risk on native organisms in the Niger Delta water sheds. This shall provide critical tools for formulating regulations and appropriate management options.

Acknowledgement: We wish to express our gratitude to the Institute of Pollution Studies Rivers State University of Science and Technology, Port Harcourt and Department of Environmental Zoology, University of Port Harcourt for the opportunity of providing grants for this research work. We also thank Messrs. Ikoro, Hanson Uyi and Loveday Jonathan for their field and laboratory assistance.

\section{REFERENCES}

Bosveld, T. A. C., Gradener, J., Murk, A. J. Brouwer, A. van Kampen M., Evers E. H. G. and Van Den berg, M. (1995). Effects of PCDDs, PCDFs and PCBs in common tern (Sterna hirundo) in estuarine and coastal colonies in the Netherlands and Belgium. Environ. Toxicol. And Chemistry, 14 (1), $99-115$.
Bosveld, T. A. C., Gradener, J., van Kampen M., Murk, A. Evers E. H. G. and Van Den berg, M. (1993). Occurrence and effects of PCBs, PCDDs, PCDFs in hatchlings of the common tern (Sterna hirundo). Chemosphere 27: 419 - 427.

Chindah A C (1998). The effect of industrial activities on the periphyton community at the upper reaches of New Calabar River, Niger Delta, Nigeria. Wat. Res. 32 (4) 1137 - 1143

Chindah, A. C., Braide S. A. \& Nduaguibe U. M. (2001). Tolerance of periwinkle (Tympanotonus fuscatus Linne) and shrimp (Palemonetes africanus Balss) to wastewater from Bonny light crude oil tank farm. Polish J. Environmental Protection and Natural Resources. 21/22: 61 - 72.

Chindah, A. C. Sikoki, F D, and Vincent-Akpu I. (2000). The effect of organochlorine pesticides on juveniles of a common wetland fish Tilapia guineensis. J. Agric. Biotech. Environ., 1 (2): 75- 82.

Dambo, W.B. (1993). Tolerance of the periwinkles Pachymelania aurita (Muller) and Tympanotonus 
fuscatus (Linne) to refined oils. J. Environmental Pollution, 79., 293 - 296.

Dieter, C. D., Duffy, W. G. and Flake L. D. (1996). The effect of phorate on wetland macroinvertebrate. Environm. Toxicol. \& Chem. 15:(3), $308-321$.

Edwards, C. A. \& Fusher, S. W. (1991). The use of chlorinesterases measurements in assessing the impacts of pesticides on terrestrial and aquatic invertebrates. In P. Mineau, ed. Chlorinesterases - inhibiting insecticides. Their impact on wild and the environment. Elsevier, Amsterdam, The Netherlands, pp. $255-275$

Fryday, S.N.L.., Andrw, D. M., Hart, A. D. M., and Langton S. D. (1996). Effects of exposure to an organophosphate pesticide on the behaviour and use of cover by Captive starlings. Environ. Toxicol. and Chem. 15: (9) 1590 - 1596.

Grillitsch, B; Vogl, C. \& Wytek, R. (1999). Qualification of spontaneous undirected locomotor behavoiur of fish for sublethal toxicity testing. Part II. Variability of measurement parameters under toxicant induced stress. Environ. Toxicol. \& Chem. , 18(12): $2743-2750$.

Grues, C. E. , Fleming W. G., Busby D. G. and Hill E. J. (1983). Assessment hazards of organophosphate pesticides to wildlife. Trans. N. Am. Wildl. Nat. Resour. Conf. 48: $200-$ 220.

Habig, C and Di Guillo R. T. (1991). Biochemical characteristics of cholinesterase - inhibiting organisms. In P. Mineau, ed., cholinesterase inhibiting insecticides, Their impact on wildlife and the environment. Elsevier, Amsterdam, The Netherlands, pp 19 - 33. deactivating nervous system.

Hontela, A; Daniel C ; Rasmuussen, J.B. (1997). Structural and functional impairment of the hythalamo-pitutary interrenal axis in fish exposed to bleached kraft mill effluent in St. Maurice River, Quebec. Ecotoxicology 6: 1-12.

Kerting, K and van Wijngaarden, R. (1992). Effects of chloropyrifos on a microecosystem. Environ. Contam. Toxicol. 11: 365 - 372.

Krugh B. W. \& Milses D. (1996). Monitoring the effects of five "non herbicidal" pesticide chemicals on terrestrial plants using chlorophyll fluorescence. Environ Toxicol. Chem.. 15:495 500.

Leight, A. E. \&Van Dolah, R. F. (1999). Acute toxicity of the insecticide endosulfan, chlorophyrifos and malathion to the epibenthic estuarine amphipod Gammarus palustris (Bousfield). Environ. Toxicol. Chem.,18(50): $958-964$

MCLeese, D. W.,; Metcalfe, D.D. \& Zitko, V. (1980). Lethality of permetrin, cypermethrin and fenvalerate to salmon, lobster and shrimp. Bull. Environ. Contam. Toxicol., 25: 290 955.

Omoregie, E. (1995). Effect of petroleum in Nile tilapia and its helminthes infection Ph.D Thesis, University of Jos, Jos, Nigeria. 152pp.

Omoregie, E., Ufodike, E.B.C. \& Keke, I.R. (1990). Tissue chemistry of $O$. niloticus exposed to sublethal concentrations of Gammalin 20 and Actellic 25EC. J. of Aquatic Science, 5:33-36.

Pratt, J. R. \& Cairns, J. C. (1996). Ecotoxicology and the redundancy problem: Understanding effects on community structure and function. In: Newman MC, Jagoe CH, (eds), Ecotoxicology: A hierarchical treatment. CRC, Boca Raton, FL, USA, pp347 - 370.

Reish, D. J. \& Oshida, P. S. (1986). Manual of methods in aquatic environmental research Part 10 short-term static bioassays. FAO Fish Technical Paper (247) 62pp.

Sikoki, F. D. \& Enajekpo, H.O.S. (1991). Effects of the water soluble fraction of crude oil on some haematological factors and liver glucose in O. niloticus. Paper presented at the $6^{\text {th }}$ annual conference of the Nigerian Association for aquatic science held at the University of Benin, 11 pp

Singh, B. B. \& Narain, A.D (1982). Acute toxicity of thiodan to catfish, Heteropmeustes fossilis. Bull. Environ. Contam. Toxicol., 28:22-27.

Singh, N. N.; Srivastava, K. A. \& Srivastava K. A.(1992). Blood dyscrasis in fresh water Indian catfish after acute exposure to a sublethal concentration of propoxur. ACTA Hydrobiol., 34: 189-195. 
Scheck, C. B. (1990). Physiological, behavioural, and performance indicators of stress. In: Adams S.M. (eds) Biological indicators of stress in fish, American Fisheries Society, Bethesda, MD pp 29 - 37.

Stein, J. E., Collier, W. L., Reichert, E, Casillas, T., Hom T. and Varanasi. (1992). Bioindicators of contaminant exposure and sublethal effects: Studies with benthic fish in Puget Sound, Washington. Environ. Tocicol. Chem. 11: 701 - 714.

USEPA. (1995). Environmental effects of database (EEDIB) Office of pesticide Programmes, Environmental Fate and Effects Division United State Environmental Protection Agency, Washington, DC.
Victor, R; Ogbeibu T (1986). Recolonisation of macrobenthic invertebrates in a Nigerian stream after persticide treatment and associated distruption. Environ. Pollut. (Ser. A) 41: 125 - 137 .

Wedemayer, G. A; Yasutake, W. T. (1977). Clinical methods for the assessment of the effects of environmental stress on fish health. US Fish and wildlife service Tech. Paper 89 Washington D.C 18.

Weber, D.N; Spieler R. E. (1994). Behavioural mechanisms of metal toxicity in fishes. In: Malins D.C; Osstrander, G.K. (eds) Aquatic Toxicology, molecular, biochemical and cellular perspectives, Lewis , Boca,raton, FL, USA, pp421 - 467. 